\title{
ANALISIS PENERIMAAN PAJAK HOTEL PADA KANTOR BADAN PENGELOLA PAJAK DAN RETRIBUSI DAERAH KOTA MANADO
}

\author{
Indah Diah Lestari ${ }^{1}$, Hendrik Manossoh $^{2}$, Dhullo Afandi ${ }^{3}$ \\ ${ }^{1,2,3}$ Fakultas Ekonomi dan Bisnis, Jurusan Akuntansi, Universitas Sam Ratulangi, J1.Kampus Bahu, Manado, \\ 95115, Indonesia \\ E-mail : Lestariindah14@gmail.com
}

\begin{abstract}
Hotel tax is a local tax imposed under the law number 28 of 2009 on local taxes and user charges. The guidelines for the management of regional finances and procedures for the implementation of regional revenue managed by the treasurer of revenue has been regulated in the Minister of Home Affairs Regulation number 59 at 2007 article 89. The purpose of this study to analyze the adequacy of the Tax Admission System and Procedure At the Office of Manado Regional Tax and Retribution Agency. The method used is descriptive analysis. Data were obtained through field studies. The result of this research is the Implementation of Hotel Tax Admission System and Procedure at the Office of Regional Tax and Retribution Manado City has been suitable with the applicable regulations from the Minister of Home Affairs Regulation number 59 at 2007 includes the related functions and documents used as well as the division of tasks and responsibilities. So it is expected that in the next year the Manado Regional Tax and Retribution Board may renew the Regulation of the Minister of Home Affairs or the applicable local government regulation concerning the System and Procedure of Revenue of Original Revenue, especially for the Hotel Tax to be better and effective.
\end{abstract}

Keywords: Hotel Tax Reception, Local Tax, Tax Admission System

\section{PENDAHULUAN}

Secara garis besar Pajak merupakan sumber pendapatan daerah yang sangat penting. Pajak merupakan sumber penerimaan utama negara yang digunakan untuk membiayai pengeluaran pemerintah dan pembangunan. Hal ini tertuang dalam Anggaran Penerimaan dan Belanja Negara (APBN) dimana penerimaan pajak merupakan penerimaan dalam negeri yang terbesar. Pajak Daerah merupakan salah satu sumber pendanaan dalam penyelenggaraan pemerintah daerah, karena pendanaan dan pembiayaan yang dipungut dari sektor pajak sangat diperlukan untuk menunjang kegiatan pembangunan di daerah. Sesuai dengan penetapan Undang-Undang nomor 28 tahun 2009 pasal 2 tentang perubahan atas Undang-Undang Republik Indonesia Nomor 18 Tahun 1997 dan Undang-Undang nomor 34 Tahun 2000 tentang Pajak Daerah dan Retribusi Daerah, perlu disesuaikan dengan kebijakan otonomi daerah.

Salah satu jenis Pajak Daerah adalah Pajak Hotel, yang lebih tepatnya, termasuk dalam Pajak Kabupaten/Kota. Pajak Hotel merupakan pajak terhadap pelayanan yang disediakan oleh hotel. Hotel merupakan fasilitas penyedia jasa penginapan atau peristirahatan, termasuk jasa terkait lainnya dengan dipungut bayaran, yang mencakup juga motel, losmen, gubuk pariwisata, wisma pariwisata, pesanggrahan, rumah penginapan dan sejenisnya, serta rumah kos dengan jumlah kamar lebih dari 10 (sepuluh). Pajak hotel merupakan pajak daerah yang pelaksanannya mengacu pada undang-undang nomor 28 tahun 2009 tentang pajak daerah dan retribusi. 


\section{TINJAUAN PUSTAKA}

\subsection{Akuntansi}

Akuntansi adalah suatu aktivitas jasa yang terdiri dari mencatat, mengklasifikasikan, dan melaporkan kejadian atau transaksi ekonomi yang akhirnya akan menghasilkan suatu informasi keuangan yang akan dibutuhkan oleh pihak-pihak tetentu untuk pengambilan keputusan (Sujarweni, 2015:1)

Menurut Mulyadi (2014:2) "Akuntansi adalah proses pencatatan, penggolongan, dan penyajian dengan cara-cara tertentu, transaksi keuangan yang terjadi dalam perusahaan atau organisasi lain serta penafsiran terhadap hasilnya"

\subsection{Akuntansi Perpajakan}

Pengertian akuntansi pajak menurut Agoes dan Estralita (2013:10) "Akuntansi pajak adalah menetapkan besarnya pajak terutang berdasarkan laporan keuangan yang disusun oleh perusahaan". Akuntansi pajak, merupakan bagian dalam akuntansi yang timbul dari unsur spesialisasi yang menurut keahlian dalam bidang tertentu. Akuntansi pajak tercipta karena adanya suatu prinsip dasar yang diatur dalam UU perpajakan dan pembentukannya terpengaruh oleh fungsi perpajakan dalam mengimplementasikan sebagai kebijakan pemerintah.

Djoko Muljono (2014 : 3), menyatakan bahwa Akuntansi Pajak adalah bidang akuntansi yang berkaitan dengan perhitungan perpajakan, yang mengacu pada peraturan, undang-undang, dan aturan pelaksanaan perpajakan.

\subsection{Fungsi Pajak}

Selain berfungsi sebagai sumber dana (budgetair ) pajak juga dapat berfungsi untuk mengatur atau melaksanakan kebijakan tertentu (reguleren), Fungsi Redistribusi serta Fungsi Demokrasi. (Agus, 2016)

1. Fungsi Penerimaan (Budgetair) Pajak berfungsi sebagai sumber dana yang diperuntukkan bagi pembiayaan pengeluaran-pengeluaran pemerintah. Dalam APBN Pajak merupakan sumber penerimaan dalam negeri.

2. Fungsi Mengatur (Reguleren) Pajak berfungsi sebagai alat untuk mengatur atau melaksanakan kebijakan di bidang sosial dan ekonomi, misalnya PPn BM untuk minuman keras dan barang-barang mewah lainnya.

3. Fungsi Redistribusi pendapatan yaitu penerimaan negara dari pajak digunakan untuk membiayai pengeluaran umum dan pembangunan nasional sehingga dapat membuka kesempatan kerja dengan tujuan untuk meningkatkan pendapatan masyarakat.

4. Fungsi Demokrasi, Pajak dalam fungsi demokrasi merupakan wujud sistem gotong royong. Fungsi ini dikaitkan dengan tingkat pelayanan pemerintah kepada masyarakat pembayar pajak

\subsection{Cara Pemungutan Pajak}

Cara pemungutan pajak menurut Siti Resmi (2013:8) dibagi menjadi tiga yaitu sebagai berikut:

1. Stelsel Nyata (Riil)

Stelsel ini menyatakan bahwa pengenaan pajak didasarkan pada objek yang sesungguhnya terjadi (untuk pph maka objeknya adalah penghasilan). Oleh karena itu, pemungutan pajaknya baru dapat dilakukan pada akhir tahun pajak, yaitu setelah semua penghasilan yang sesungguhnya dalam suatu tahun pajak diketahui. Kelebihan stelsel nyata adalah penghitungan pajak didasarkan pada penghasilan yang sesungguhnya sehingga lebih akurat dan realistis. Kekurangan stelsel nyata adalah pajak baru dapat diketahui pada akhir periode, sehingga:

a. Wajib pajak akan dibebani jumlah pembayaran pajak yang tinggi pada akhir tahun sementara pada waktu tersebut belumtentu tersedia jumlah kas yang memadai; dan 
b. Semua wajib pajak akan membayar pajak pada akhir tahun sehingga jumlah uang beredar secara makro akan berpengaruh.

2. Stelsel Anggapan (fiktif)

Stelsel ini menyatakan bahwa pengenaan pajak didasarkan pada suatu anggapan yang diatur oleh undang-undang. Sebagai contoh, penghasilan suatu tahun dianggap sama dengan penghasilan tahun sebelumnya sehingga pajak yang terutang pada suatu tahun juga dianggap sama dengan pajak yang terutang tahun sebelumnya.Dengan stelsel ini berarti besarnya pajak yang terutang pada tahun berjalan sudah dapat ditetapkan atau diketahui pada awal tahun yang bersangkutan. Kelebihan stelsel fiktif adalah pajak dapat dibayar selama tahun berjalan, tanpa harus menunggu sampai akhir suatu tahun, misalnya pembayaran pajak dilakukan pada saat wajib pajak memperoleh penghasilan tinggi atau mungkin dapat diangsur dalam tahun berjalan. Kekurangannya adalah pajak yang dibayar tidak berdasar pada keadaan yang sesungguhnya, sehingga penentuan pajak menjadi tidak akurat.

3. Stelsel campuran

Stelsel ini menyatakan bahwa pengenaan pajak didasarkan pada kombinasi antara stelsel nyata dan stelsel anggapan. Pada awal tahun, besarnya pajak dihitung berdasarkan suatu anggapan, kemudian pada akhir tahun besarnya pajak dihitung berdasar keadaan yang sesungguhnya. Jika besarnya pajak berdasar keadaan sesungguhnya lebih besar dari pada besarnya pajak menurut anggapan, wajib pajak harus membayar kekurangan tersebut. Sebaliknya, jika besarnya pajak sesungguhnya lebih kecil dari pada besarnya pajak menurut anggapan, kelebihan tersebut dapat diminta kembali (restitusi) ataupun dikompensasikan pada tahun-tahun berikutnya, setelah diperhitungkan dengan utang pajak yang lain".

\subsection{Sistem Pemungutan Pajak}

B. Ilyas dan Burton (2013:37) menyebutkan terdapat empat macam sistem pemungutan pajak yaitu sebagai berikut:

1. Official Assessment System

Suatu sistem pemungutan pajak yang memberi wewenang kepada pemungut pajak (fiskus) untuk menentukan besarnya pajak yang harus dibayar (pajak yang terutang) oleh seseorang.

Dengan sistem ini masyarakat (Wajib Pajak) bersifat pasif dan menunggu dikeluarkannya suatu ketetapan pajak oleh fiskus. Besarnya utang pajak seseorang baru diketahui setelah adanya surat ketetapan pajak.

2. Semiself Assessment System

Suatu sistem pemungutan pajak yang memberi wewenang pada fiskus dan Wajib Pajak untuk menentukan besarnya pajak seseorang yang terutang. Dalam sistem ini, setiap awal tahun pajak Wajib Pajak menentukan sendiri besarnya pajak yang terutang untuk tahun berjalan yang merupakan angsuran bagi Wajib Pajak yang harus disetor sendiri. Baru kemudian pada akhir tahun pajak fiskus menentukan besarnya utang pajak yang sesungguhnya berdasarkan data yang dilaporkan oleh Wajib Pajak.

3. Self Assessment System

Suatu sistem pemungutan pajak yang memberi wewenang penuh kepada Wajib Pajak untuk menghitung, memperhitungkan, menyetorkan, dan melaporkan sendiri besarnya utang pajak.

Dalam sistem ini Wajib Pajak yang aktif sedangkan fiskus tidak turut campur dalam penentuan besarnya pajak yang terutang seseorang, kecuali Wajib Pajak melanggar ketentuan yang berlaku.

4. Withholding System

Suatu sistem pemungutan pajak yang memberi wewenang pada pihak ketiga untuk memotong/memungut besarnya pajak yang terutang. Pihak ketiga yang telah ditentukan tersebut selanjutnya menyetor dan melaporkannya kepada fiskus. Pada sistem ini, fiskus 
dan Wajib Pajak tidak aktif. Fiskus hanya bertugas mengawasi saja pelaksanaan pemotongan/pemungutan yang dilakukan oleh pihak ketiga.

\subsection{Jenis-jenis Pajak Daerah}

Dalam pengelolaan pemungutan Pajak Daerah berpedoman pada peraturan perundang-undangan. Menurut UU Nomor 28 Tahun 2009 tentang Pajak daerah dan Retribusi Daerah, menyebutkan jenis-jenis Pajak Daeah terdiri dari:

1. Jenis Pajak Provinsi terdiri dari :

a. Pajak Kendaraan Bermotor;

b. Bea Balik Nama Kendaraan Bermotor;

c. Pajak Bahan Bakar Kendaraan Bermotor;

d. Pajak Air Permukaan; dan

e. Pajak Rokok

2. Jenis Pajak Kabupaten/Kota terdiri dari :

a. Pajak Hotel;

b. Pajak Restoran;

c. Pajak Hiburan;

d. Pajak Reklame;

e. Pajak Penerangan Jalan;

f. Pajak Mineral Bukan Logam dan Batuan;

g. Pajak Parkir;

h. Pajak Air Tanah;

i. Pajak Sarang Burung Walet;

j. Pajak Bumi dan Bangunan Perdesaan dan Perkotaan; dan

k. Bea Perolehan Hak atas Tanah dan Bangunan

\subsection{Tarif Pajak Daerah}

Tarif Pajak merupakan salah satu bagian penting dalam penerimaan pajak dalam meningkatkan pendapatan negara di banyak negara berkembang (Tonin:2013). Pada UU Nomor 28 Tahun 2009 telah ditentukan besaran tarif pajak yang dapat ditetapkan oleh pemerintah daerah untuk masing-masing jenis pajak daerah. Tarif pajak yang diatur adalah tarif paling tinggi, sebagai berikut :

1. Tarif PKB ditetapkan paling tinggi $10 \%$.

2. Tarif BBNKB ditetapkan paling tinggi $20 \%$.

3. Tarif PPBKB ditetapkan paling tinggi $10 \%$.

4. Tarif Pajak Air Permukaan ditetapkan paling tinggi $10 \%$.

5. Tarif Rokok ditetapkan paling tinggi $10 \%$.

6. Tarif Pajak Hotel ditetapkan paling tinggi $10 \%$.

7. Tarif Pajak Restoran ditetapkan paling tinggi $10 \%$.

8. Tarif Pajak Hiburan ditetapkan paling tinggi $35 \%$.

9. Tarif Pajak Reklame ditetapkan paling tinggi $25 \%$.

10. Tarif Pajak Penerangan Jalan ditetapkan paling tinggi $10 \%$.

11. Tarif Pajak Mineral Bukan Logam dan Batuan yang ditetapkan paling tinggi sebesar $25 \%$.

12. Tarif Pajak Parkir ditetapkan paling tinggi $30 \%$.

13. Tarif Pajak Air Tanah ditetapkan paling tinggi sebesar 30\%.

14. Tarif Pajak Sarang Burung Walet ditetapkan paling tinggi sebesar $10 \%$.

15. Tarif PBB Perdesaan dan Perkotaan ditetapkan paling tinggi sebesar 0,3\%.

16. Tarif BPHTB ditetapkan paling tinggi sebesar 5\%.

Besarnya pokok pajak yang dihitung dengan cara mengalikan tarif pajak dengan pengenaan pajak. Cara perhitungan ini digunakan setiap jenis pajak daerah. 


\section{METODE PENELITIAN}

\subsection{Jenis dan Sumber Data}

Dalam penelitian ini, jenis data yang digunakan penulis adalah jenis data kualitatif yang bersifat deskriptif. Secara umum, jenis data terbagi dua, yaitu data kualitatif dan kuantitatif. Jenis data kualitatif merupakan data yang disajikan secara deksriptif atau berbentuk uraian, sedangkan jenis data kuantitatif adalah data yang disajikan dalam bentuk angka-angka. Sumber data yang digunakan dalam penelitian ini adalah data primer dan data sekunder.

\subsection{Teknik Pengumpulan Data}

Teknik yang penulis pakai dalam pengumpulan data adalah Penelitian Lapangan (field research). Teknik ini dilakukan dengan melaksanakan wawancara dengan pegawai dan pimpinan untuk memperoleh data yang diperlukan dalam penelitian ini. Data yang diperoleh yaitu sistem prosedur penerimaan Pajak Hotel, serta dokumentansi untuk data target dan realisasi penerimaan pendapatan daerah untuk 3 Tahun Terakhir dan data-data lain yang berhubungan dengan penelitian ini.

\subsection{Metode Analisis Data}

Metode analisis yang digunakan dalam penelitian ini adalah metode analisis deksriptif. Metode analisis ini dimulai dengan langkah mengumpulkan dan menyaring keterangan-keterangan yang diperoleh secara menyeluruh dan detail, kemudian diuraikan sehingga diperoleh gambaran yang jelas.

\section{HASIL ANALISIS DAN PEMBAHASAN \\ 4.1 Hasil Analisis}

1) Analisis Penerimaan Pajak Hotel di Kantor Badan Pengelola Pajak dan Retribusi Daerah Kota Manado

Penerimaan Pajak Hotel dilihat dari Target dan Realisasi yang digunakan sebagai tolak ukur dalam melihat bagaimana cara pemungutan pajak hotel ditentukan oleh Tim Anggaran dari Pemerintah Daerah, dimana di dalamnya melibatkan pihak dari bagian keuangan Badan Pengelolaan Pajak dan Retribusi Daerah Kota Manado. Untuk Menganalisis Penerimaan Pajak Hotel di Kota Manado maka harus diketahui terlebih dahulu Target dan Realisasi Penerimaan Pajak Hotel di Kota Manado. Untuk membandingkan antara Realisasi dan Target dilakukan dengan cara Rasio Efektivitas.

Mahmudi (2010:143) menyatakan bahwa efektivitas merupakan hubungan antara keluaran dengan tujuan atau sasaran yang harus dicapai. Dikatakan efektif apabila proses kegiatan mencapai tujuan dan sasaran akhir kebijakan (spending wisely). Adapun cara untuk mengukur efektivitas pemungutan pajak adalah sebagai berikut:

$$
\begin{array}{llll}
\text { Efektivitas } & \text { Realisasi Penerimaan Pajak } & \text { x } & 100 \%
\end{array}
$$

Dan tingkat efektivitas digolongkan ke dalam beberapa kategori berikut :

Tabel 4.1 Rasio Efektivitas

\begin{tabular}{|l|l|}
\hline Rasio Efektivitas (100\%) & Kriteria \\
\hline$>100 \%$ & Sangat Efektif \\
\hline $90 \%-100 \%$ & Efektif \\
\hline $80 \%-90 \%$ & Cukup Efektif \\
\hline $60 \%-80 \%$ & Kurang Efektif \\
\hline$<60 \%$ & Tidak Efektif \\
\hline
\end{tabular}

Sumber : Mahmudi (2010) 
Apabila hasil perhitungan efektivitas Pajak Hotel menghasilkan angka/persentase mendekati $100 \%$ atau melebihi, maka Pajak Hotel semakin efektif atau dengan kata lain tingkat peberimaan pajak hotel di Kota Manado semakin baik. Dibawah ini disajikan tabel perhitungan efektivitas pajak hotel Kota Manado 3 tahun terakhir (2015-2017):

Tabel 4.2 Target dan Realisasi Pajak Hotel Kota Manado Tahun 2015-2017

\begin{tabular}{|l|l|l|l|l|}
\hline $\begin{array}{l}\text { Tahun } \\
\text { Anggaran }\end{array}$ & Target $(\mathrm{Rp})$ & Realisasi (Rp) & $\begin{array}{l}\text { Presentase } \\
\text { Efektivitas }(\%)\end{array}$ & Keterangan \\
\hline 2015 & 18.000 .000 .000 & 18.108 .799 .451 & $100,61 \%$ & EFEKTIF \\
\hline 2016 & 20.900 .000 .000 & 25.425 .453 .862 & $121,65 \%$ & EFEKTIF \\
\hline 2017 & 23.500 .000 .000 & 29.964 .047 .338 & $127,51 \%$ & EFEKTIF \\
\hline
\end{tabular}

Sumber: Badan Pengelola Pajak dan Retribusi Daerah Kota Manado

\section{Sistem dan Prosedur Penerimaan Pajak Hotel di Kantor Pengelola Pajak dan Retribusi Daerah Kota Manado}

Penerimaan Pajak Hotel Pada Badan Pengelola Pajak dan Retribusi Daerah kota Manado dilaksanakan dengan pembagian tugas dan fungsi masing- masing. Sistem yang dipakai dalam penerimaan Pajak Hotel di Badan Pengelola Pajak dan Retribusi Daerah Kota Manado adalah Self Assessment System yaitu Suatu sistem pemungutan pajak yang memberi wewenang penuh kepada Wajib Pajak untuk menghitung, memperhitungkan, menyetorkan, dan melaporkan sendiri besarnya utang pajak.

Dalam sistem ini Wajib Pajak yang aktif sedangkan fiskus tidak turut campur dalam penentuan besarnya pajak yang terutang seseorang, kecuali Wajib Pajak melanggar ketentuan yang berlaku.

Jaringan prosedur yang membentuk sistem penerimaan pajak Hotel di Badan Pengelola Pajak dan Retribusi Daerah Kota Manado sebagai berikut:

1. Fungsi pihak terkait

a. PPK- SKPD Adalah pejabat yang melaksanakan fungsi tata usaha keuangan pada SKPD.

b. Pengguna anggaran Adalah pejabat pemegang kewenangan penggunaan anggaran untuk melaksanakan tugas pokok dan fungsi SKPD yang dipimpinnya.

c. Bendahara penerimaan Adalah pejabat fungsional yang ditunjuk untuk menerima, menyimpan, menyetorkan, menatausahakan, dan mempertanggungjawabkan uang pendapatan daerah dalam rangka pelaksanaan APBD pada SKPD.

d. BUD (BANK) Adalah PPKD yang bertindak dalam kapasitas sebagai bendahara umum daerah.

2. Dokumen yang digunakan

a. Laporan Hasil Penjualan dan Pemakaian Nota Penjualan Pajak Daerah (Pajak Hotel)

b. Surat Pemberitahuan Pajak daerah (SPTPD) Pajak Hotel

c. Surat Tanda Setoran (STS)

d. Nota Kredit Bank

3. Catatan yang digunakan

a. Buku Besar

b. Buku Besar Pembantu 
4. Deskripsi Prosedur

Pelaksanaan sistem prosedur penerimaan pajak Hotel di kota Manado dilakukan melalui bendahara penerimaan, bendahara penerimaan pembantu dan pendapatan daerah melalui bank pemerintah yang ditunjuk.

1. Prosedur Penerimaan Pajak Hotel melalui bendahara penerimaan.

Bendahara penerimaan menerima pembayaran sejumlah uang yang tertera pada SPTPD dari wajib pajak lalu memverivikasi kesesuian jumlah uang yang diterima dengan dokumen Laporan Hasil Penjualan dan Pemakai Nota Penjualan Pajak Daerah yang diterima dari PPK-SKPD kemudian bendahara penerimaan membuat Surat Tanda Setoran (STS), lalu menyerahkan tanda bukti tersebut kepada wajib pajak.

2. Penerimaan Pajak Hotel melalui Bendahara pembantu.

Bendahara Penerimaan Pembantu ditunjuk untuk daerah yang kondisi geografisnya sulit dijangkau wajib pajak,yang tidak dapat membayar kewajibannya secara langsung pada badan atau lembaga keuangan yang terkait. Bendahara Penerimaan Pembantu menerima sejumlah uang yang tertera pada SPTPD dari wajib pajak lalu memverifikasi kesesuaian jumlah uang yang diterima tersebut. Kemudian bendahara penerimaan membuat Surat Tanda Setoran (STS), selanjutnya Bendahara Penerimaan Pembantu menyerahkan tanda bukti penerimaan atau tanda bukti lain yang sah kepada wajib pajak.

3. Prosedur Penerimaan Pajak Hotel melalui Bank Kas Daerah (BANK SULUT).

Penerimaan Pajak Hotel dapat disetor ke rekening kas daerah dengan cara disetor langsung ke Bank yang ditunjuk. Bank kas daerah menerima pembayaran sejumlah uang yang tertera pada SPTPD lalu menerbitkan slip setoran / bukti setoran lain yang sah dan nota kredit, selanjutnya bank kas daerah menyerahkan slip setoran / bukti lain yang sah kepada wajib pajak dan nota kredit kepada Badan Pengelola Pajak dan Retribusi Daerah Kota Manado.

Tabel 4.3 Penerimaan Pajak Hotel Pada Badan Pengelola Pajak dan Retribusi Kota Manado

\begin{tabular}{|c|c|c|c|}
\hline No. & Pelaksanaan & Langkah & Aktivasi \\
\hline 1. & PPKD & 1 & $\begin{array}{l}\text { Menyerahkan formulir laporan hasil penjualan dan } \\
\text { pemakaian nota penjualan pajak daerah beserta SPTPD yang } \\
\text { telah diterbitkan kepada PPK. }\end{array}$ \\
\hline 2. & PPK & 2 & $\begin{array}{l}\text { Menyerahkan formulir laporan hasil penjualan dan } \\
\text { pemakaian nota penjualan pajak daerah kepada Wajib Pajak } \\
\text { yang terkait. }\end{array}$ \\
\hline 3. & Wajib Pajak & 3 & $\begin{array}{l}\text { Mengisi Formulir Laporan Hasil Penjualan dan Pemakaian } \\
\text { Nota Penjualan Pajak Daerah berdasarkan pendapatan yang } \\
\text { dihasilkan dari pajak Hotel (dalam hal ini peruasahaan yang } \\
\text { terkait). }\end{array}$ \\
\hline 4. & SKPD & 4 & $\begin{array}{l}\text { Menyerahkan formulir SPTPD kepada Wajib Pajak yang } \\
\text { terkait, setelah Wajib Pajak mengisi Formulir Laporan Hasil } \\
\text { Penjualan dan Pemakaian Nota Penjualan Pajak Daerah. } \\
\text { Setelah mengisi formulir SPTPD Wajib Pajak yang terkait } \\
\text { diarahkan untuk menyetorkan setoran pajak kepada } \\
\text { Bendahara Penerima / Bank yang ditunjuk daerah (BANK } \\
\text { SULUT). }\end{array}$ \\
\hline 5. & Bendahara Penerima & 7 & $\begin{array}{l}\text { Memverifikasi kesesuaian jumlah setoran pajak dengan } \\
\text { formulir SPTPD. } \\
\text { Menerima setoran pajak dari Wajib Pajak yang terkait, } \\
\text { kemudian Bendahara Penerima membuat Surat Tanda } \\
\text { Setoran (STS). }\end{array}$ \\
\hline
\end{tabular}




\subsection{Pembahasan}

\subsubsection{Analisis Penerimaan Pajak Hotel Pada Kantor Badan Pengelola Pajak dan Retribusi Daerah Kota Manado}

Dari Hasil Penelitian dan data Target dan Realisasi seperti pada tabel 4.2 di atas dapat diketahui bahwa realisasi penerimaan Pajak Hotel sudah memenuhi target yang di tetapkan bahkan melebihi. Pada tahun 2015 realisasi dari penerimaan Pajak Hotel sudah melebihi dari target yang telah ditetapkan Pemerintah Kota Manado yaitu sebesar Rp. 18.000.000.000 , dan yang terealisasi melebihi dari target yaitu 18.108.799.451.

Pada tahun 2016 yang realisasi penerimaannya mengalami kenaikan sebesar Rp. 7.316.654.411 dari tahun 2015 menjadi Rp. 25.425.453.862 dari target yang sudah di tentukan pada tahun tersebut sebesar 20.900.000.000. Sedangkan realisasi penerimaan pajak hotel ditahun tersebut melebihi target dan mengalami kenaikan sebesar Rp.4.525.453.862 dari tahun sebelumnya.

Pada tahun 2017 target penerimaan Pajak Hotel mengalami kenaikan yang luar biasa yaitu sebesar Rp. 2.600.000.000, sedangkan realisasi penerimaan Pajak Hotel ditahun tersebut melebihi dari target yang ditetapkan dan mengalami kenaikan sebesar Rp. 6.464.047.338 dari tahun sebelumnya.

Dari uraian diatas dapat disimpulkan bahwa target penerimaan Pajak Hotel yang terendah terjadi pada tahun 2015, sedangkan yang tertinggi terjadi ditahun 2017. Untuk realisasi penerimaan Pajak Hotel cukup meningkat dari tahun 2015 ke 2017 , dan yang terendah terjadi ditahun 2015 karena mengalami selisih terendah dari tahun berikutnya, sedangkan yang tertinggi terjadi ditahun 2017.

Untuk selisih target penerimaan dan realisasi penerimaan Pajak Hotel dari tahun ke tahun mengalami perubahan dan dapat kita lihat bahwa selisih antara target penerimaan dan realisasi penerimaan Pajak Hotel yang mengalami penurunan terjadi ditahun 2015. Selisih target penerimaan dan realisasi penerimaan yang mengalami perubahan setiap tahun disebabkan karena target penerimaan pajak yang selalu berubah-ubah setiap tahun dan juga realisasi penerimaan pajak yang berubah setiap tahun yang dikarenakan oleh kesadaran Wajib Pajak.

Perubahan target penerimaan dan realisasi penerimaan Pajak Hotel dapat kita lihat dalam diagram batang berikut ini:

\section{Gambar 4.1 Target Penerimaan dan Realisasi Penerimaan Pajak Hotel}

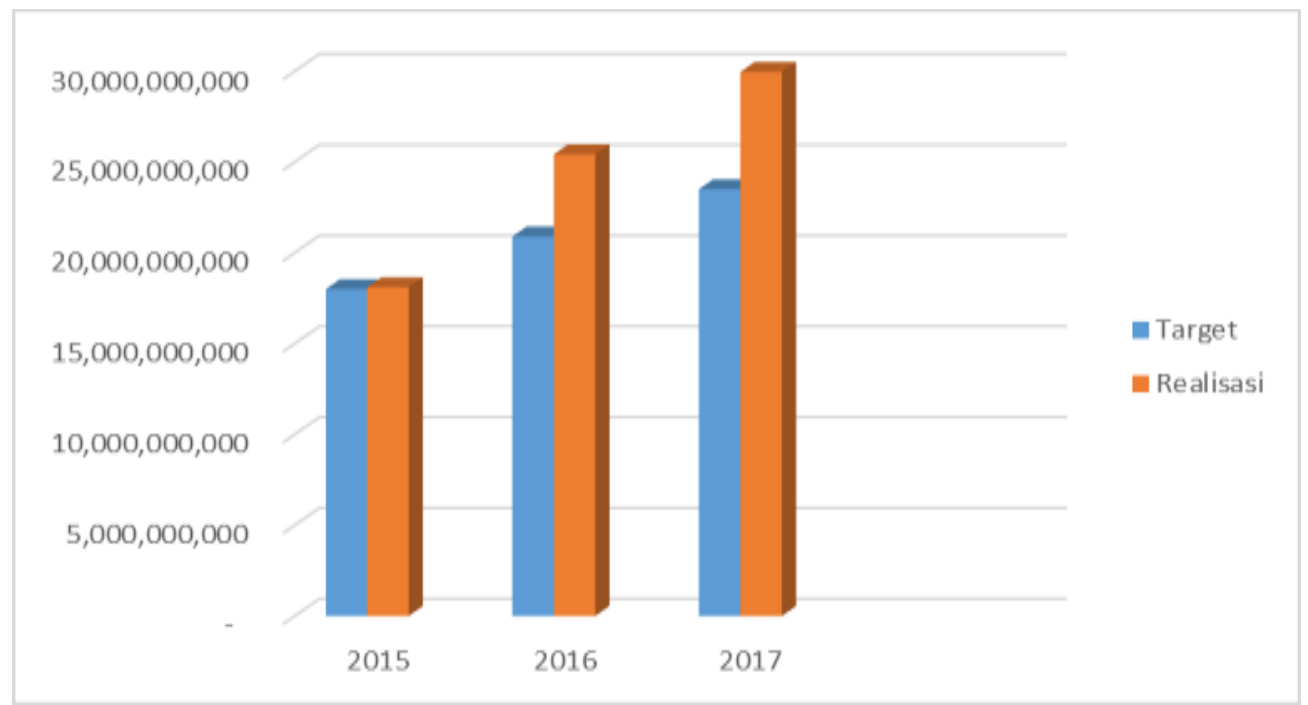

Sumber : Hasil Pengolahan Data (selisih target dan realisasi Pajak Pajak) 
4.2 Analisis Sistem dan Prosedur Penerimaan Pajak Hotel di Kantor Pengelola Pajak dan Retribusi Daerah Kota Manado

1. Sistem Prosedur Penerimaan Pajak Hotel di Badan Pengelola Pajak dan Retribusi Daerah Kota Manado telah sesuai dengan Permendagri Nomor 59 Tahun 2007 pada surat edaran tentang Sistem dan Prosedur Pengelolaan Keuangan Daerah yang berisi ketentuan Sistem Prosedur Penerimaan kas, pelaksanaan penerimaan kas disetor ke rekening kas umum daerah pada bank Pemerintah yang ditunjuk dan kemudian bank mengirim nota kredit sebagai pemeberitahuan atas setoran tersebut ke fungsi yang melaksanakannya. Dimana dalam menjalankan Sistem Prosedur Penerimaan Pajak Hotel, Badan Pengelola Pajak dan Retribusi Daerah Kota Manado membagi tugas dan tanggung jawab kedalam beberapa fungsi yaitu pengguna anggaran , PPK/SKPD, Bendahara Penerimaan dan Bank.

2. Wajib Pajak menyetor uang (Setoran Pajak), kemudian Bendahara Penerimaan melakukan verifikasi dokumen SPTPD dan membuat Surat Tanda Setor (STS). Untuk pembayaran Pajak Hotel dilakukan paling lambat tanggal 15 bulan yang berjalan, apabila Wajib Pajak terlambat dalam menyetorkan setoran Pajak maka Badan Pengelola Pajak dan Retribusi Daerah Kota Manado mengenakan denda sebesar 2\% dari total setoran pajak yang dibayarkan Wajib Pajak tersebut.

3. Dan juga apabila pembayaran dilakukan oleh Wajib Pajak langsung ke kas Daerah (Bank SULUT), maka oleh kas daerah dibuatkan slip setoran sebanyak 2 lembar yang diserahkan kepada Wajib Pajak. Dari 2 lembar slip setoran yang ditrimaWajib Pajak tersebut salah satunya diserahkan kepada Bendahara Penerimaan, Bendahara Penerimaan membuat surat tanda bukti pembayaran dan menyerahkan kepada Wajib Pajak.

4. Jika pembayaran dilakukan Wajib Pajak melalui Bendahara Penerimaan Pembantu, maka alurnya sama dengan Pembayaran melalui Bendahara Penerimaan, namun seluruh bukti penerimaan dan bukti setoran dibuat surat pertanggungjawaban (SPJ) oleh Bendahara Penerimaan Pembantu dan diserahkan ke Bendahara Penerimaan. Hal ini dapat dilihat dalam tabel berikut:

\section{Tabel 4.2 Analisis Sistem dan Prosedur Penerimaan Pajak Daerah Pada Badan}

Pengelola Pajak dan Retribusi Daerah Kota Manado

\begin{tabular}{|c|c|c|c|}
\hline No & $\begin{array}{l}\text { Permendagri } 59 \text { Tahun } 2007 \text { Pasal } 89 \\
\text { (dalam surat edaran) }\end{array}$ & Hasil Penelitian & Ket \\
\hline 1. & Pihak / Fungsi Terkait & $\begin{array}{l}\text { Pembagian tugas / fungsi antara menyimpan dan yang } \\
\text { mencatat dalam hal ini fungsi penyimpanan ini PPK- } \\
\text { SKPD, PA, Bendahara Penerimaan dan Bagian } \\
\text { Pembukuan / Akuntansi }\end{array}$ & Sesuai \\
\hline 2. & Aktivasi & $\begin{array}{l}\text { Dalam pelaksanaan aktivitas terdapat prosedur } \\
\text { penyetoran bukti kas masuk (SKP/STS dan Nota } \\
\text { Kredit Bank) yang dimulai PA, Wajib Pajak, } \\
\text { Bendahara Penerimaan dan selanjutnya uang disetor ke } \\
\text { Bank }\end{array}$ & Sesuai \\
\hline 3. & Dokumen & $\begin{aligned} & \text { Terdapat dokumen penyetoran yaitu : } \\
& \text { a. } \\
& \text { Laporan Hasil Penjualan dan Pemakaian } \\
& \text { Nota Penjualan Pajak Daerah (Pajak Hotel) } \\
& \text { b. } \\
& \text { Surat Pemberitahuan Pajak daerah (SPTPD) } \\
& \text { c. } \\
& \text { d. } \text { Surat Tanda Sota Kredit Bank }\end{aligned}$ & Sesuai \\
\hline
\end{tabular}

Sumber: Hasil Pengolahan Data 


\section{KESIMPULAN DAN SARAN}

\subsection{Kesimpulan}

Berdasarkan hasil penelitian dan pembahasan mengenai Analisis Penerimaan Pajak Hotel Pada Kantor Badan Pengelola Pajak dan Retribusi Daerah Kota Manado maka diperoleh beberapa kesimpulan sebagai berikut:

1. Sistem Penerimaan Pajak Hotel di Badan Pengelola Pajak dan Retribusi Daerah Kota Manado menggunakan Self Assessment System yaitu Suatu sistem pemungutan pajak yang memberi wewenang penuh kepada Wajib Pajak untuk menghitung, memperhitungkan, menyetorkan, dan melaporkan sendiri besarnya utang pajak.

2. Pelaksanaan sistem dan prosedur penerimaan Pajak Hotel pada Kantor Pengelola Pajak dan Retribusi Daerah Kota Manado telah sesuai dengan peraturan yang berlaku yaitu Peraturan Menteri Dalam Negeri No. 59 Tahun 2007 yang mencakup fungsi yang terkait dan dokumen yang digunakan serta pembagian tugas dan tanggung jawab kedalam beberapa fungsi yaitu PPK-SKPD, Bank,

\subsection{Saran}

Bendahara Penerimaan dan Bagian Pembukuan/Akuntansi.

Berdasarkan kesimpulan yang sudah disebutkan dalam penelitian ini. Maka saran yang dapat diberikan penulis adalah sebagai berikut.

1. Diharapkan agar pelayanan dari Badan Pengelola Pajak dan Retribusi Daerah bisa lebih maksimal dan terarah. Serta dapat meningkatkan Kesadaran Wajib Pajak agar realisasi bisa terlaksana sesuai Target yang di tentukan.

2. Kantor ini masih perlu perhatian dari pemerintah untuk mengatur ketentuan yang jelas dalam menentukan target penerimaan Pajak Hotel sehingga target penerimaan pajak setiap tahunnya dapat terealisasi seperti pada data yang saya ambil 3 tahun terakhir dan di usahakan untuk tetap konsisten dalam menambah pendapatan per tahunnya.

3. Kota Manado khususnya Badan Pengelola Pajak dan Retribusi Daerah harus perlu terus mengupdate Peraturan Menteri Dalam Negeri atau peraturan pemerintah daerah yang berlaku mengenai Sistem dan Prosedur Penerimaan Pendapatan Asli Daerah khususnya Pajak Hotel lebih baik dan efektif.

\section{DAFTAR PUSTAKA}

Agoes, Sukrisno dan Estralita Trisnawati. 2013. Akuntansi Perpajakan Edisi 3. Jakarta: Salemba Empat.

Agus. 2016. Pengampunan Pajak (Tax Amnesty) Sebagai Upaya Optimalisasi Fungsi Pajak. Jurnal Ekonomi Keuangan, dan Manajemen, Volume 12, (2). ISSN online: 2528-1097

A. Ilyas dan Burton. 2013. Hukum Pajak. Edisi 6. Salemba Empat. Jakarta

Dian Indra. 2013. Potensi Dan efektifitas Pajak Hotel Di Kabupaten Semarang. Fakultas Ekonomi Universitas Negeri Semarang 2103.

Dunia, Firdaus. 2013. Pengantar Akuntansi. Edisi ke-3. Jakarta FE-UI

GASB Concepts Statement No. 1, Objectives of Financial Reporting: 62-68)

Giri, Efraim Ferdinan. Akuntansi Keuangan Menengah 1. 2017. Edisi kedua. Yogyakarta: UPP STIM YKPN.

Irwansyah.2014. Efektifitas dan kontribusi pajak hotel terhadap pendapatan asli daerah,Fakultas ekonomi dan bisnis universitas dipenogoro semarang

Mardiasmo, 2013. Perpajakan Indonesia. Edisi Revisi. Andi. Yogyakarta

Mardiasmo. 2016. Perpajakan Edisi Revisi. ANDI.Yogyakarta 
Mahmudi. 2011. Akuntansi Sektor Publik. Penerbit UII Press Yogyakarta

Mulyadi. Sistem Akuntansi. 2014. Edisi ketiga. Universitas Gadjah Mada: Salemba Empat.

Mulyono, Djoko 2014. Akuntansi Pajak. Jakarta: Salemba Empat

Peraturah Pemerintah Nomor 71 Tahun 2010. Tentang Standar Akuntansi Pemerintah. Jakarta.

Sujarweni, V. Wiratna. Sistem Akuntansi. 2015. Bandung: Pustaka Baru Press.

Suandy. 2014. Hukum Pajak. Edisi 6. Salemba Empat. Jakarta

Suyanto, 2016. Tax Amnesty. Universitas Sarjanawiyata Tamansiswa Jogjakarta. Jurnal Akuntansi Vol. 4 No. 2

ToninMirc, 2013.Reporting Import Tariff (and other tax). Journal International Tax and Public Finance Volume 21 (1) pages 153-173

Undang-undang Nomor 33 Tahun 2004 tentang pertimbangan keuangan antara pemerintah pusat dan daerah pasal 1 ayat 18

Undang-undang Nomor 12 Tahun 2008 tentang Pemerintah Daerah

Undang-undang Nomor 32 Tahun 2004 Pasal 157 Sumber-sumber Pendapatan Daerah.

Undang-undang Nomor 28 tahun 2009 pasal 2 tentang perubahan ata UU Repulik Indonesia

Nomor 18 Tahun 1997 dan Undang-undang Nomor 34 tahun 2000 tentang Pajak daerah dan Retribusi Daerah

Undang-undang Nomor 28 tahun 2009 tentang Pajak Daerah dan Retribusi

Peraturan Daerah Kota Manado Nomor 2 Tahun 2011 tentang Pajak Daerah

Undang-undang No. 36 Tahun 2008 Bab II tentang Subjek Pajak Pasal 2 ayat 1

Undang-undang No. 36 Tahun 2008 Bab II tentang Subjek Pajak Pasal 4 ayat 1

Undang-undang No. 11 Tahun 2016 pasal 1 ayat 2 tentang Definisi Wajib Pajak

Peraturan Walikota Nomor 61 Tahun 2016 pasal 3

Undang-undang KUP Nomor 16 Tahun 2009

Peraturan Menteri Dalam Negeri Nomor 59 Tahun 2007 